\title{
Gambaran Keterikatan Kerja pada Dosen-Tetap Ditinjau dari Karakteristik Personal
}

\author{
Zamralita \\ Fakultas Psikologi, Universitas Tarumanagara \\ Email:zamralita@fpsi.untar.ac.id
}

\begin{abstract}
ABSTRAK
Dosen merupakan sumber daya manusia yang sangat penting bagi suatu perguruan tinggi.Dosen adalah pendidik profesional dan ilmuwan dengan tugas utama mentransformasikan, mengembangkan, dan menyebarluaskan ilmu pengetahuan, teknologi, dan seni melalui Tridharma Perguruan Tinggi (pendidikan, penelitian, dan pengabdian kepada masyarakat). Dosen-Tetap yang memiliki kinerja tinggi sangat dibutuhkan untuk menghasilkan lulusan yang berkualitas. Kinerja dosen yang tinggi dapat dicapai jika dosen memiliki keterikatan dengan pekerjaannya. Tujuan penelitian ini untuk mendapatkan gambaran keterikatan kerja pada dosen-tetap ditinjau dari karakteristik personal.Teori yang digunakan adalah teori keterikatan kerja. Keterikatan kerja diartikan sebagai motivasi dan pikiran positif yang berhubungan dengan pekerjaan yang dicirikan dengan aspek vigour, dedication, dan absorption (Schaufeli \& Bakker, 2003). Metode yang digunakan dalam penelitian ini adalah metode kuantitatif. Partisipan penelitian adalah dosen-tetap yang berjumlah 602 orang. Data penelitian diperoleh melalui kuesioner keterikatan kerja.Analisis data menggunakan independent sample t-test dan one way anova. Hasil penelitian menunjukkan bahwa dosen-tetap memiliki keterikatan kerja yang tinggi $(M=4,21)$, dan memiliki skor yang tinggi pada semua dimensinya, vigor $(M=4,18)$, dedication $(M=4,28)$, dan absorption $(M=4,16)$. Selain itu diperoleh hasil, semakin meningkatnya usia dan masa kerja, maka keterikatan kerja semakin tinggi. Jika dikaitkan dengan tingkat pendidikan dan jabatan fungsional dosen, semakin tinggi tingkat pendidikan dan jabatan fungsional dosen, semakin tinggi keterikatan kerja. Namun, jika dianalisis berdasarkan jenis kelamin, tidak terdapat perbedaan keterikatan kerja antara dosen laki-laki dan perempuan.
\end{abstract}

Kata kunci: keterikatan kerja, karakteristik personal, dosen tetap.

\section{PENDAHULUAN}

Dosen adalah pendidik profesional dan ilmuwan dengan tugas utama mentransformasikan, mengembangkan dan menyebarkan ilmu pengetahuan, teknologi dan seni melalui pendidikan, penelitian dan pengabdian kepada masyarakat. Tugas utama Dosen adalah melaksanakan tridharma perguruan tinggi dengan beban kerja paling sedikit sepadan dengan 12 (dua belas) sks dan paling banyak 16 (enam belas) sks pada setiap semester sesuai dengan kualifikasi akademiknya. Tugas utama dosen terdiri dari: (1) tugas di bidang pendidikan dan pengajaran, (2) tugas di bidang penelitian dan pengembangan karya ilmiah, (3) tugas melakukan pengabdian pada masyarakat, (4) tugas penunjang tridharma perguruan tinggi.(Undang-undang Republik Indonesia nomor 14 tahun 2005 tentang Guru dan Dosen).

Dosen merupakan unsur yang sangat menentukan keberhasilan proses pendidikan dan merupakan ujung tombak perguruan tinggi. Ditangan para dosen yang berkualitas, mahasiswa dibentuk menjadi manusia cerdas yang dapat meningkatkan mutu sumber daya manusia. Oleh sebab itu, peran dosen di perguruan tinggi merupakan modal bagi perguruan tinggi.

Berdasarkan survey yang dilakukan oleh Tempo pada tahun 2010, salah satu indikator perguruan tinggi yang baik, adalah dosen yang berkualitas. Kriteria lainnya adalah lulusan cepat dan mudah mendapatkan pekerjaan, memiliki reputasi sebagai perguruan tinggi swasta yang bagus, mudah dijangkau, lulusannya banyak bekerja pada berbagai bidang, sarana belajar mengajar memadai. Selain itu, program studi yang dipilih terkenal/bagus, Perguruan Tinggi tersebut memiliki ijin operasional dari Dirjen Pendidikan Tinggi, status akreditasi program studi yang dipilih, program studi yang dipilih banyak yang diminati orang. Hal lain yang menjadi kriteria adalah biaya kuliah terjangkau, lulusannya banyak menjadi orang terkenal, jumlah Dosen dan mahasiswa seimbang, kedisiplinan kampus baik, serta fisik gedung bagus. (Tempo, 2010). 
Jika dilihat dari kriteria pemilihan Perguruan Tinggi terbaik dari Buku Tempo, kualitas dosen merupakan kriteria yang penting. Dosen sebagai salah satu unsur di Perguruan Tinggi berperan sangat besar dalam mewujudkan kualitas Perguruan Tinggi, khususnya dalam peningkatan kualitas proses pembelajaran. Selain itu,dosen memiliki peranan penting karena merupakan ujung tombak bagi perguruan tinggi sebagai pihak yang menyampaikan jasa di bidang pendidikan dan pengajaran pada mahasiswa.

Dosen yang berkualitas dapat dilihat melalui kinerjanya yang tinggi dan kinerja yang tinggi akan dapat tercapai jika dosen memiliki keterikatan yang tinggi dengan pekerjaannya. Dosen yang memiliki keterikatan yang tinggi dengan pekerjaannya akan merasa antusias, bersemangat, dan tekun mengerjakan tugas-tugasnya, memandang pekerjaan dan tugas-tugasnya sebagai sesuatu yang bermakna, serta memiliki konsentrasi penuh dalam menjalankan tugasnya.

Bakker, seorang ahli dalam kajian keterikatan kerja mengungkapkan keterikatan kerja adalah prediktor utama untuk kinerja individu, dibandingkan konstruk-konstruk yang terdahulu (Bakker, 2011).Terdapat beberapa alasan mengapa karyawan yang memiliki keterikatan kerja yang tinggi akan memiliki kinerja yang baik. Pertama, karyawan merasakan dan mengalami emosi yang positif seperti semangat, gembira, dan antusias dalam mengerjakan tugas-tugasnya. Kedua, emosi positif yang dirasakan karyawan, membuat karyawan memiliki kesehatan yang baik. Ketiga, dengan ksehatan yang baik, mereka dapat berkonsentrasi dan menyalurkan secara utuh seluruh energi dan keterampilan mereka pada pekerjaan, sehingga dapat menciptakan nilai lebih bagi pekerjaan mereka dan sumber daya yang mereka miliki. Keseluruhan hal ini membuat karyawan yang terikat dengan pekerjaannya memiliki kinerja yang tinggi dan dapat menyalurkan engagement mereka pada lingkungan terdekat (Bakker \& Demerouti, 2008).

Keterikatan kerja memiliki dampak yang sangat positif bagi individu maupun organisasi, karena keterikatan kerja adalah sikap yang positif terhadap pekerjaan dan organisasi tempat kerjanya. Dari penelitian-penelitian yang telah dilakukan, keterikatan kerja terbukti memiliki pengaruh terhadap kepuasan kerja, komitmen organisasional, dan kecenderungan turn over yang rendah (Schaufeli \& Bakker, 2003), perilaku organisasi yang positif, kinerja, perilaku extra role, perilaku proaktif (Salanova, Agut,\& Peiro, 2005) serta kesehatan, berupa rendahnya tingkat depresi dan distress (Schaufeli \& Salanova, 2007).

Keterikatan kerja diartikan sebagai motivasi dan pikiran positif yang berhubungan dengan pekerjaan yang dicirikan dengan aspek vigour, dedication, dan absorption (Schaufeli \& Bakker, 2004). Menurut Schaufeli dan Bakker (2003), konsep keterikatan kerja terdiri dari 3 dimensi, yaitu:vigour, dedication, dan absorption.

Vigour adalah besarnya energi dan daya tahan, kemampuan untuk berusaha, tidak mudah menyerah dan mampu menghadapi kesulitan.Tingginya skor dimensi vigour, menunjukkan adanya energi, semangat, dan stamina saat bekerja. Dedication adalah merasa terlibat sangat kuat dengan pekerjaan dan mengalami rasa kebermaknaan, antusiasme, kebanggaan, inspirasi dan tantangan. Absorption adalah merasa senang dan bahagia saat bekerja, memiliki konsentrasi, dan fokus pada pekerjaan, hinggawaktu terasa berlalu sangat cepat.

Terdapat beberapa hasil penelitian (Bakker, Gierveld,\& Van Rijswijk, 2006) yang menjelaskan keterkaitan antara keterikatan kerja dan kinerja. Bakker et al.(2006) menjelaskan hubungan antara keterikatan kerja dan kinerja pada sampel kepala sekolah dan guru. Penelitian lain dilakukan oleh Schaufeli, Taris, dan Bakker (2006) yang menguji hubungan antara keterikatan 
kerja dan kinerja. Hasil studi tersebut menemukan keterikatan kerja berhubungan positif dengan kinerja in-role, kinerja extra-role, dan inovasi. Studi lain yang dilakukan oleh Bakker dan Bal (2010) menemukan bahwa keterikatan kerja memiliki hubungan positif dengan kinerja dan menjelaskan pentingnya keterikatan kerja bagi guru. Selain itu terdapat studi lain yang menjelaskan keterikatan kerja dapat memprediksi kinerja. (Bakker, Demerouti,\& Verbeke, 2004).

Dari beberapa hasil penelitian diatas, keterikatan kerja merupakan hal yang penting karena berdampak pada kinerja dan diklaim sebagai prediktor utama dari kinerja, sehingga penelitian mengenai keterikatan kerja pada dosen perlu dilakukan. Tujuan penelitian ini untuk mengkaji keterikatan kerja dan karakteristik personal yang turut memengaruhi keterikatan kerja antara lain jenis kelamin, usia, masa kerja, tingkat pendidikan, dan jabatan fungsional dosen.

\section{METODE PENELITIAN}

\section{Karakteristik Partisipan}

Karakteristik subjek dalam penelitian ini adalah dosen-tetap universitas swasta terbaik di Indonesia (Tempo, 2010), usia 25-75 tahun, minimal masa kerja 3 tahun. Berikut ini akan diuraikan data responden berdasarkan jenis kelamin, usia, masa kerja, status pernikahan, tingkat pendidikan, dan jabatan fungsional dosen.

Tabel 1. Gambaran data responden berdasarkan jenis kelamin

\begin{tabular}{lcc}
\hline Jenis kelamin & Jumlah & Persentase \\
\hline Laki-laki & 333 & $55 \%$ \\
Perempuan & 269 & $45 \%$ \\
\hline Total & 602 & $100 \%$ \\
\hline
\end{tabular}

Tabel 2. Gambaran data responden berdasarkan usia

\begin{tabular}{lcc}
\hline Usia & Jumlah & Persentase \\
\hline$<30$ tahun & 70 & 12 \\
$31-40$ tahun & 185 & 31 \\
41-50 tahun & 168 & 28 \\
$51-60$ tahun & 112 & 18 \\
61-70 tahun & 58 & 10 \\
$>70$ tahun & 9 & 1 \\
\hline Total & 602 & $100 \%$ \\
\hline
\end{tabular}

Tabel 3. Gambaran data responden ditinjau dari masa kerja

\begin{tabular}{rcc}
\hline Masa kerja & Jumlah & Persentase \\
\hline $3-10$ tahun & 249 & $41 \%$ \\
$11-20$ tahun & 179 & $30 \%$ \\
$21-30$ tahun & 126 & $21 \%$ \\
$31-40$ tahun & 39 & $6 \%$ \\
$>40$ tahun & 9 & $2 \%$ \\
\hline Total & 602 & $100 \%$ \\
\hline
\end{tabular}

Tabel 4. Gambaran data responden ditinjau dari status pernikahan

\begin{tabular}{lcc}
\hline Status Pernikahan & Jumlah & Persentase \\
\hline Lajang & 110 & $18 \%$ \\
Menikah & 472 & $78 \%$ \\
Duda/janda & 20 & $4 \%$ \\
\hline Total & 602 & $100 \%$ \\
\hline
\end{tabular}


Tabel 5. Gambaran data responden ditinjau dari tingkat pendidikan

\begin{tabular}{lcc}
\hline Tingkat Pendidikan & Jumlah & Persentase \\
\hline S2 & 482 & $80 \%$ \\
S3 & 120 & $20 \%$ \\
\hline Total & 602 & $100 \%$ \\
\hline
\end{tabular}

Tabel 6. Gambaran data responden ditinjau dari jabatan fungsional dosen (JFD)

\begin{tabular}{lcc}
\hline Jabatan Fungsional Dosen (JFD) & Jumlah & Persentase \\
\hline Asisten Ahli & 212 & $35 \%$ \\
Lektor & 225 & $37 \%$ \\
Lektor Kepala & 153 & $26 \%$ \\
Guru Besar & 12 & $2 \%$ \\
Total & 602 & $100 \%$ \\
\hline
\end{tabular}

Penelitian ini merupakan penelitian kuantitatif. Teknik sampling yang digunakan dalam penelitian ini adalah purposive (non-probability) sampling. Data diperoleh dengan menyebarkan kuesioner pada partisipan penelitian. Kuesioner yang digunakan adalah kuesioner keterikatan kerja yang diadaptasi dari kuesioner yang dikembangkan oleh Schaufeli dan Bakker (2003). Kuesioner keterikatan kerja memiliki koefisien reliabilitas internal yang baik untuk setiap dimensinya (dimensi vigour $=0,873$; dimensi dedication $=0,887$; dan dimensi absorption $=$ 0,837).Contoh butir untuk dimensi vigour adalah "saya merasa bersemangat ketika bekerja", contoh butir untuk dimensi dedication adalah "saya merasa pekerjaan yang saya lakukan memiliki makna dan manfaat yang jelas", contoh butir untuk dimensi absorption adalah "ketika bekerja, saya merasa waktu berlalu begitu cepat".

\section{Hasil dan Pembahasan}

Data dianalisis dengan menggunakan metode descriptive statistics,independent sample t-test, dan one way anova.

\section{Gambaran Keterikatan Kerja}

Berikut ini dibahas gambaran keterikatan kerja pada dosen tetap. Kategori yang akan digunakan adalah sebagai berikut: Rendah $=$ skor rata-rata $1-2,49$; Rata-rata $=$ skor rata-rata 2,5 -3,5; dan Tinggi $=$ skor rata-rata 3,51-5,00.

Dosen-tetap memiliki keterikatan kerja yang tinggi, artinya dosen mengerjakan tugas-tugasnya dengan senang dan bersemangat, memiliki perasaan bangga dengan pekerjaannya sebagai dosen, tekun dan berkonsentrasi penuh dalam mengerjakan tugas-tugasnya(Schaufeli \& Bakker, 2003). Jika ditelaah per dimensi, dimensi vigour, dedication dan absorption memiliki skor tinggi yang dapat dilihat pada Tabel 7.

Tabel 7. Gambaran keterikatan kerja

\begin{tabular}{lcc}
\hline Keterikatan Kerja & Rata-rata & Kategori \\
\hline Vigour & 4,18 & Tinggi \\
Dedication & 4,28 & Tinggi \\
Absorption & 4,16 & Tinggi \\
Keterikatan Kerja & 4,21 & Tinggi \\
\hline
\end{tabular}

\section{Gambaran Keterikatan Kerja ditinjau dari Jenis Kelamin}

Seluruh dosen-tetap memiliki skor keterikatan kerja yang tinggi dan tidak terdapat perbedaan skor keterikatan kerja antara dosen laki-laki dan perempuan, artinya dosen laki-laki dan perempuan memiliki skor keterikatan kerja yang tinggi, yang dapat dilihat pada Tabel 8 . Hal ini 
agak berbeda dengan hasil penelitian yang dilakukan oleh Schaufeli, Bakker, dan Salanova (2006) yang menemukan bahwa karyawan laki-laki lebih engaged dalam bekerja dibandingkan karyawan perempuan. Pada profesi dosen, tidak ditemukan adanya perbedaan yang signifikan antara dosen laki-laki dan perempuan. Dosen laki-laki dan perempuan mengerjakan tugas-tugas yang sama berkaitan dengan Tridharma Perguruan Tinggi yang meliputi pendidikan dan pengajaran, penelitian, dan pengabdian pada masyarakat.

Tabel 8. Gambaran keterikatan kerja ditinjau dari jenis kelamin

\begin{tabular}{lccc}
\hline Keterikatan Kerja & $\begin{array}{c}\text { Rata-Rata } \\
\text { Laki-Laki }\end{array}$ & $\begin{array}{c}\text { Rata-Rata } \\
\text { Perempuan }\end{array}$ & Signifikansi \\
\hline Vigour & 4,22 & 4,13 & 0,033 \\
Dedication & 4,28 & 4,28 & 0,913 \\
Absorption & 4,19 & 4,12 & 0,070 \\
Keterikatan Kerja & 4,23 & 4,18 & 0,135 \\
\hline
\end{tabular}

\section{Gambaran Keterikatan Kerja Ditinjau dari Usia}

Jika ditinjau dari usia, seluruh dosen-tetap memiliki skor keterikatan kerja yang tinggi. Jika ditelusuri lebih lanjut,dosen-tetap yang memiliki usia diatas 30 tahun memiliki skor keterikatan kerja yang lebih tinggi dibandingkan yang berusia di bawah 30 tahun (Tabel 9). Hal ini sejalan dengan penelitian yangdilakukan oleh Schaufeli et al. (2006) yang menganalisis kembali 27 penelitian yang dilakukan antara tahun 1999 sampai 2003. Schaufeli et al.menemukan ada hubungan positif, tetapi lemah, antara usia dan keterikatan kerja. Sedangkan pada profesi dosen, umumnya dosen merasa semakin engaged dalam mengerjakan tugas-tugasnya dalam bidang pendidikan dan pengajaran, penelitian, dan pengabdian pada masyarakat, sejalan dengan bertambahnya usia.

Tabel 9. Gambaran keterikatan kerja ditinjau dari usia

\begin{tabular}{lcccccc}
\hline \multirow{2}{*}{ Keterikatan Kerja } & $<30$ & $31-40$ & $41-50$ & $51-60$ & $61-70$ & $>70$ \\
& Tahun & Tahun & Tahun & tahun & Tahun & Tahun \\
\hline Vigour & 3,91 & 4,11 & 4,22 & 4,31 & 4,30 & 4,39 \\
Dedication & 4,05 & 4,23 & 4,37 & 4,37 & 4,35 & 4,19 \\
Absorption & 3,95 & 4,07 & 4,21 & 4,28 & 4,29 & 4,46 \\
Keterikatan Kerja & 3,97 & 4,14 & 4,27 & 4,32 & 4,32 & 4,34 \\
\hline
\end{tabular}

\section{Gambaran Keterikatan Kerja ditinjau dari Masa Kerja}

Dosen-Tetap yang memiliki masa kerja diatas 10 tahun memiliki skor keterikatan kerja yang lebih tinggi dibandingkan dosen-tetap yang memiliki masa kerja di bawah 10 tahun, demikian pula dengan dimensi vigour, dedication, dan absorption, yang dapat dilihat pada Tabel 10 . Artinya, keterikatan kerja dapat meningkat sejalan dengan bertambahnya masa kerja. Hal ini sejalan dengan penelitian yang dilakukan oleh Schaufeli et al. (2006) yang menemukan ada hubungan positif antara masa kerja dan keterikatan kerja. Khususnya pada profesi dosen, dengan bertambahnya masa kerja, pengalaman semakin banyak, wawasan semakin luas, dan keterampilan meningkat yang membuat dosen semakin cepat mengerjakan tugas-tugasnya dan memiliki dedikasi tinggi pada tugasnya yang berkaitan dengan Tridharma Perguruan Tinggi.

Tabel 10. Gambaran keterikatan kerja ditinjau dari masa kerja

\begin{tabular}{lccccc}
\hline Keterikatan Kerja & $\begin{array}{c}3-10 \\
\text { tahun }\end{array}$ & $\begin{array}{c}11-20 \\
\text { Tahun }\end{array}$ & $\begin{array}{c}21-30 \\
\text { tahun }\end{array}$ & $\begin{array}{c}31-40 \\
\text { tahun }\end{array}$ & $\begin{array}{c}>40 \\
\text { Tahun }\end{array}$ \\
\hline Vigour & 4,04 & 4,27 & 4,27 & 4,33 & 4,33 \\
Dedication & 4,16 & 4,38 & 4,36 & 4,34 & 4,32 \\
Absorption & 4,02 & 4,25 & 4,26 & 4,30 & 4,35 \\
Keterikatan kerja & 4,07 & 4,30 & 4,30 & 4,33 & 4,33 \\
\hline
\end{tabular}




\section{Gambaran Keterikatan Kerja Ditinjau dari Tingkat Pendidikan}

Seluruh dosen-tetap memiliki skor keterikatan kerja yang tinggi. Jika ditelusuri lebih lanjut,dosen-tetap yang memiliki tingkat pendidikan S3 memiliki skor keterikatan kerja lebih tinggi dibandingkan S2, demikian juga untuk dimensi vigour, dedication, danabsorption (Tabel 11). Hal ini sejalan dengan penelitian yang dilakukan oleh Hakanen, Bakker,dan Schaufeli (2006) yang mengungkapkan semakin tinggi tingkat pendidikan, semakin individu terikat dengan pekerjaannya.Tampaknya hal ini disebabkan oleh peningkatan strata pendidikan, sejalan dengan peningkatan wawasan pengetahuan dan keterampilan. Hal ini membuat dosen semakin antusias, bersemangat, dan tekun dalam mengerjakan tugas-tugasnya sehingga keterikatan kerja dosen semakin tinggi.

Tabel 11. Gambaran keterikatan kerja ditinjau dari tingkat pendidikan

\begin{tabular}{lcc}
\hline Keterikatan Kerja & S2 & S3 \\
\hline Vigour & 4,15 & 4,30 \\
Dedication & 4,26 & 4,39 \\
Absorption & 4,13 & 4,28 \\
Keterikatan kerja & 4,18 & 4,32 \\
\hline
\end{tabular}

\section{Gambaran Keterikatan Kerja Ditinjau dari Jabatan Fungsional Dosen (JFD)}

Jika ditinjau dari Jabatan Fungsional Dosen, Guru Besar memiliki skor keterikatan kerja lebih tinggi dibandingkan Lektor Kepala, Lektor dan Asisten Ahli, demikian juga untuk dimensi vigour, dedication, dan absorption yang dapat dilihat pada Tabel 12. Berdasarkan Tabel 12, dapat dilihat bahwa semakin tinggi jabatan fungsional maka skor keterikatan kerjanya akan semakin tinggi, namun terlihat perbedaan yang signifikan antara Asisten Ahli dengan Lektor, Lektor Kepala dan Guru Besar. Hal ini dapat disebabkan oleh kriteria atau persyaratan yang digunakan untuk memperoleh Jabatan Fungsional yang lebih tinggi, dibutuhkan persyaratan tridharma perguruan tinggi yang semakin banyak dan tuntutan yang semakin tinggi. Dosen perlu mengumpulkan angka kredit terkait dengan ketiga kegiatan ini dengan bobot yang sudah ditetapkan dan berbeda. Ketiga kegiatan ini dapat saling mendukung dan melengkapi, dapat meningkatkan kompetensi dosen dalam mengerjakan tugas-tugasnya, serta dapat membuat Dosen semakin bersemangat, antusias, dan tekun dalam berkarya.

Tabel 12. Gambaran keterikatan kerja ditinjau dari jabatan fungsional dosen

\begin{tabular}{lcccc}
\hline Keterikatan Kerja & Asisten Ahli & Lektor & Lektor Kepala & Guru Besar \\
\hline Vigour & 4,05 & 4,18 & 4,34 & 4,43 \\
Dedication & 4,17 & 4,30 & 4,40 & 4,46 \\
Absorption & 4,03 & 4,16 & 4,33 & 4,35 \\
Keterikatan kerja & 4,09 & 4,21 & 4,36 & 4,42 \\
\hline
\end{tabular}

\section{KESIMPULAN DAN SARAN}

Kesimpulan dari penelitian ini adalah dosen-tetap memiliki keterikatan kerja yang tinggi dan memiliki skor yang tinggi pada semua dimensinya vigour, dedication, dan absorption. Selain itu diperoleh hasil, semakin meningkatnya usia dan masa kerja, maka keterikatan kerja semakin tinggi. Jika dikaitkan dengan tingkat pendidikan dan jabatan fungsional dosen, semakin tinggi tingkat pendidikan dan jabatan fungsional dosen, maka semakin tinggi keterikatan kerja yang dimiliki. Dosen yang bergelar Doktor memiliki keterikatan kerja yang lebih tinggi dibandingkan dosen yang bergelar Magister. Dosen yang memiliki jabatan fungsional Lektor, Lektor Kepala dan Guru Besar memiliki keterikatan kerja yang lebih tinggi dibandingkan Asisten Ahli. Namun, jika dianalisis berdasarkan jenis kelamin, tidak terdapat perbedaan keterikatan kerja antara dosen 
laki-laki dan perempuan; karena dosen laki-laki dan perempuan mempunyai tugas yang sama yang berkaitan dengan tridharma perguruan tinggi.

Adapaun saran berdasarkan hasil penelitian ini, diharapkan dosen-tetap dapat mempertahankan dan meningkatkan keterikatan kerja karena keterikatan kerja merupakan prediktor utama dari kinerja. Dosen diharapkan untuk mengembangkan diri dan menempuh studi lanjut hingga memperoleh gelar Doktor karena dosen bergelar Doktor terbukti memiliki keterikatan kerja yang lebih tinggi dibandingkan Magister. Selain itu, para dosen juga disarankan untuk meraih jabatan fungsional yang tinggi, sebagai indikasi bahwa dirinya memiliki keterikatan kerja dan kinerja yang tinggi. Jabatan fungsional Lektor, Lektor Kepala,dan Guru Besar terbukti memiliki keterikatan kerja yang lebih lebih tinggi dibandingkan Asisten Ahli. Pihak fakultas dan universitas diharapkan dapat memfasilitasi mekanisme pengurusan studi lanjut dan jabatan fungsional dosen.

\section{Ucapan Terima Kasih}

Peneliti mengucapkan terima kasih pada seluruh pimpinan universitas dan prodi dari lima universitas terbaik di Indonesia yang telah mengijinkan pengambilan data dan ucapan terima kasih serta penghargaan bagi teman teman dosen yang telah berkenan menjadi partisipan.

\section{REFERENSI}

Bakker, A.B. (2011). An evidence - based model of work engagement. Current Directions in Psychological Science, 20(4), 265 - 269.

Bakker, A.B., \& Bal, P.M. (2010). Weekly work engagement and performance: A study among starting teachers. Journalof Occupational and Organizational Psychology, 83, 189-206.

Bakker, A.B.,\& Demerouti E.(2008). Towards a model of work engagement.The Journal of Career Development International, 13(3). 209-219.

Bakker, A.B., Demerouti, E., \& Verbeke, W. (2004). Using the job demands-resources model to predict burnout and performance. Human Resource Management, 43, 83-104.

Bakker, A.B., Gierveld, J.H. \&Van Rijswijk, K. (2006). Success factors amongfemale school principals in primary teaching: A study on burnout, work engagement, and performance. Right Management Consultants, Diemen.

Hakanen, J., Bakker,A. B.,\& Schaufeli, W. B. (2006). Burnout and work engagementamong teachers. Journal of School Psychology, 43, 495-513.

Salanova, M., Agut, S., \& Peiro, J. M. (2005). Linking organizational resources and work engagement to employee performance and customer royalty: The mediation of service climate. Journal of Applied Psychology, 90, 1217-1227.

Schaufeli, W. B., \& Bakker, A. B. (2003). UWES-Utrecht work engagement scale: Test manual.Department of Psychology, Utrecht University. Unpublished manuscript.

Schaufeli, W. B., \& Bakker, A. B. (2004). Job demands, job resources and their relationship with burnout and engagement: a multi-sample study. Journal of Organizational Behavior, 25(3), 293-315.

Schaufeli, W.B., \& Bakker, A.B., \& Salanova, M. (2006). The measurement of work engagement with a short questionnaire: A cross-national study. Educational and Psychological Measurement, 66, 701-716.

Schaufeli, W., \& Salanova, M. (2007). Work engagement: An emerging psychological concept and its implications for organizations. In S. W. Gilliland, D. D. Steiner, \& D. P. Skarlicki (Eds.), Managing social and ethical issues in organizations (pp. 135-177). Greenwich: Information Age Publishing. 
Schaufeli, W.B., Taris, T.W., \& Bakker, A.B.(2006). Dr. Jekyll or mr. Hyde: On the difference between work engagement and alkoholism. In R.J. Burke (Ed.). Research companion to working time and work addiction (pp. 193-217). Cheltenham, Glos, UK: Edward Elgar.

Tim Tempo. Panduan Memilih Program Studi (2010). Gramedia, Jakarta.

Undang-undang Republik Indonesia 